\title{
Race, Structure, and State Governments: The Politics of Higher Education Diversity
}

\author{
Alisa Hicklin University of Oklahoma \\ Kenneth J. Meier Texas A\&M University and Cardiff University
}

\begin{abstract}
This paper examines the politics of higher education diversity for both African Americans and Latinos, by investigating how the structure of the bureaucracy affects the relationship between descriptive and substantive representation. The key theoretical determinants of minority college enrollments are legislative representation, bureaucratic structure, university-level policies, and restrictions on affirmative action. A hierarchical linear model of 500+ universities over an 11-year period shows that each of these factors affects minority enrollments.
\end{abstract}

$\mathrm{M}$ uch of the literature concerning race and politics focuses on minority representation in legislative bodies. For some time now, scholars have studied how minority groups gain legislative seats-often termed descriptive representationand whether this increased presence produces shifts in policy that benefit that particular minority group, usually referred to as substantive representation (Hero and Tolbert 1995; Mansbridge 1999; Pitkin 1967; Preuhs 2006). We now have a body of evidence showing that, in some cases, descriptive representation translates into increased substantive representation for racial minorities. Not all studies find this relationship; however, and there is considerable variance in the strength of the relationship.

The majority of existing literature on this topic takes one of two forms. Studies either test how changes in minority representation affect legislation (Bratton and Haynie 1999; Karnig and Welch 1980; Lublin 1999), or they test how minority legislative representation affects policy outcomes (Meier, Stewart, and England 1989, Meier and Stewart 1991). These studies offer considerable insight into minority representation but are limited in their ability to speak to how representation affects the actual welfare of the groups in question. Theoretically, we can begin to take the next step, moving from asking if there is a relationship between descriptive and substantive representation to asking more nuanced questions about when, where, how, and, even more interesting, why these relationships exist in some places but not in others (Preuhs 2006). This article makes three contributions to the literature: it demonstrates how bureaucratic structures condition legislative representation; it illustrates the representation process when policies are directly tied to minority interests as in higher education; and it relies on hierarchical linear models to estimate appropriate relationships.

\section{State Governments and Minority Student Enrollments}

Higher education policy offers great potential in advancing our knowledge about minority representation. Unlike other state policy areas where we have considerable difficulty in linking a certain policy good (e.g., health care spending) to a particular minority group, racial diversity in college student bodies is a salient issue that one can directly relate to the interests of minority populations. Since higher education is controlled, in large part, by state governments, we have a natural quasi-experiment because legislative bodies vary considerably in levels of representation for both African Americans and Latinos.

Although there is a literature on higher education diversity, it has not focused on the question of the political determinants. Most of the scholarly literature is normative and deals with the benefits of diversity in higher education so that we know little 
about the factors that affect levels of minority enrollment ("Beyond" 2002; Bowen, Bok, and Loury 2000; Duderstadt 2000; Hurtado and Cade 2001). Even the existing studies only include a handful of universities, most of which are elite, Ivy League universities, concentrated in specific geographic areas (Chapa and Lazaro 1998; Horn and Flores 2003; Post 1998; Simmons 1982; Welch and Gruhl 1998). This focus on elite institutions means we have little knowledge about what affects the overwhelming majority of college students in the higher education system. Critical differences in size, selectivity, and scope have not been incorporated into much of the research; and, as a result, the modest research that we have is limited by its inapplicability to most universities. Before we can further investigate the effectiveness of various policies, however, we must first explore the macrolevel factors that shape the environment.

A considerable amount of the popular and scholarly attention that touches on the politics of diversity at American universities has focused on recent $\mathrm{Su}-$ preme Court decisions (Bowen, Bok, and Loury 2000; Chapa and Lazaro 1998; Duderstadt 2000; Hurtado and Cade 2001; Horn and Flores 2003; Post 1998: Simmons 1982). Noticeably absent from these studies is the consideration of how other institutions affect these policy outcomes. Other higher education policy areas, such as budgeting and oversight, consider a host of possible determinants, with significant focus placed on the state legislative bodies and its chief bureaucratic agency (Lowry 2001; McLendon, Heller, and Young 2005; Payne 2003).

State legislatures play a critical role in the success of public universities, serving as the primary overseer in policy, funding, and accountability. The state legislature determines the level of public funding that each university will receive, through the specification of a funding formula and through grant programs, specific projects, and other avenues. Policies concerning private universities and out-of-state students are also influenced by the state legislature, and in turn these policies affect a public university's ability to generate its own revenue. Legislatures also can regulate tuition, set statewide admissions policies, and advance policies in the K-12 system that will affect the pipeline of students who eventually feed into universities.

Because public universities are largely controlled by the state government, differences among state legislatures should influence a state's universities. In particular, we would expect that a change in the composition of the legislature could influence numerous policy issues in the state. To specify the relationship between legislative representation and policy outcomes for minority groups, we turn to the literature on descriptive and substantive representation.

Descriptive representation refers to when the demographic composition of the legislative body mirrors that of the citizenry (Pitkin 1967). In the case of state legislatures, increases in descriptive representation would mean a larger proportion of the legislative seats held by representatives of color. In the policy process, these representatives-by virtue of their presence-are "standing for" minority interests, with the expectation that the increased presence of minority legislators will result in actions that will be more favorable toward minority groups. This expectation of policy change is most often linked to theories of substantive representation or "acting for" minority groups, where we expect that having more minority representatives will result in those representatives being proactive in articulating minority interests.

Theory leads us to expect that, in most situations, any increase in minority representation will result in real policy gains for minority groups. The findings of empirical studies are mixed, however, with some finding no relationship (Cameron, Epstein, and O’Halloran 1996; Lublin 1999), others findings strong relationships (Fraga, Meier, and England 1986; Grose 2006; Meier and Stewart 1991), some pointing to only "indirect" effects (Hero and Tolbert 1996), and some identifying contextual factors that mediate this relationship (Preuhs 2006). Theoretically, descriptive and substantive representation are almost inextricably linked, as we assume that minority representatives will inevitably behave differently than their Anglo counterparts in advocating for minority interests. Empirically, however, these concepts are not always tightly coupled; and so these mixed findings lead us to ask about why the strength of this relationship varies and in what situations we would expect this relationship to be stronger.

One factor that might affect the translation of descriptive representation into substantive benefits is how closely policy outcomes are tied to minority interests. In the K-12 public education systems, a series of studies (Fraga, Meier, and England 1986; Meier and Stewart 1991) have found increased minority representation in the decision-making organization (the school board) was positively associated with increased student performance (standardized test scores, attendance, graduation rates) for minority student groups. Because higher education policy has similar outcomes directly linked to minority interests (as opposed to variables such as welfare expenditures), one would expect the same relationship between 
descriptive and substantive representation to exist in higher education.

H1: Increased minority representation in the state legislature will positively affect levels of minority student enrollments at public universities.

Hypothesis 1 allows us to test for the direct effect of minority representation on policy outcomes. State legislatures are a key actor in higher education policy and have several policy instruments that can affect minority enrollments (e.g., allocating extra money to minority-serving institutions, funding minority-targeted scholarships, etc.). We also want to consider, however, ways that elected officials can indirectly affect policy through the bureaucracy.

\section{The Influence of Structure}

To explore the factors that may strengthen or weaken the relationship between descriptive representation and minority policy outcomes, we turn to the welldeveloped literature on policy implementation and bureaucratic politics. Most germane to this study is the work on how certain bureaucratic factors, particularly structure, can influence how legislative preferences are translated into policy. Studies have argued how bureaucracies can be crafted so that the structure of the institution will institutionalize certain biases while excluding others (Knight 1992). Much of this work has focused on the structure of the relationship between legislative institutions and public agencies, contending that some structures can increase the amount of "control" the legislature can exert over individual institutions (Epstein and O'Halloran 1999; Huber and Shipan 2002).

Some of the previous work on how variations in structure and representation affect policy outcomes focuses on how differences in electoral structures affect the ways in which minority representation influences policy outcomes, particularly in the literature on school boards in the K-12 system (Meier et al. 2005). Our analysis takes a different approach, moving the attention from electoral to bureaucratic structure. We ask how variations in bureaucratic structure influence the ways that legislative representation affects policy, by considering how bureaucratic agencies can function as a filter between legislative activity and individual public organizations.

Despite the body of knowledge on how bureaucratic structures mediate the relationship between legislatures and public institutions, there have been few applications to the literature on minority policy issues. Higher education offers a unique opportunity to investigate this relationship. Minority access to higher education is a salient issue that attracts the efforts of minority legislators. The variable of interestbureaucratic structure-can also be investigated in higher education, because states differ in how the higher education community is organized, with other scholars already linking these differences to fluctuations in other types of policies (Knott and Payne 2003; Lowry 2001; McLendon 2003; McLendon, Heller, and Young 2005).

Each state has a chief bureaucratic agency that oversees its public, four-year institutions, ${ }^{1}$ and these agencies vary in a few basic respects. The explicit language used to discuss these boards differs somewhat, so for the sake of clarity, we offer some definitions. First, we refer to the state-level organization tasked with oversight of the state's public, four-year institutions as the chief bureaucratic agency. We then differentiate between these boards based on the level of centralization of these boards and their policymaking power (relative to the legislature, subordinate campus systems, and individual institutions). The more centralized system is usually called a consolidated governing board, in which one board (usually called the state regents) sets policy for all four-year, public institutions. The less centralized systems, called either coordinating boards or planning agencies, oversee multiple boards of regents which have the actual authority to set policy for smaller sets of institutions. ${ }^{2}$ Consolidated governing boards generally have greater formal authority and more autonomy in regard to setting policy. In his study of how structure affects tuition prices, Lowry (2001) finds that states with coordinating boards, which exert less control over institutions, have tuition levels that are more in line with legislative preferences. More generally, this relationship implies that a less centralized (and less powerful) agency would be more likely to implement legislative preferences.

While representation theory would predict that increases in minority representation should lead to positive gains for minority students, this assumes that the path from the legislature to the citizenry is a direct one. However, each of these states has a state-level intermediate institution, and if that institution has a

\footnotetext{
${ }^{1}$ There is some variation as to which state boards also oversee community colleges and other institutions, but such institutions are outside of the scope of this study.

${ }^{2}$ With only a few states having planning agencies, we will refer to both coordinating boards and planning agencies as coordinating boards.
} 
substantial amount of autonomy and influence, legislative preferences may be weakened during the implementation process. This weakening could take place in a number of ways, whether through the reallocation of money, the extent to which the bureaucratic agency chooses to monitor individual institutions, or the flexibility the chief agency affords the individual institutions in pursuing various initiatives. On some level, this could be seen as an issue of relative power (see Rourke 1969). Coordinating boards, as more loosely organized institutions, are relatively easy to penetrate by state legislators who are interested in pursuing certain goals. Conversely, governing boards, with higher levels of organization and control and larger professional staffs, are much more independent, inertial, and autonomous. In terms of Rourke's (1969) theory of bureaucratic power, they have greater expertise and often have independent political support that allows them to resist legislative initiatives. While we would not expect governing boards to be hostile to legislative preferences, we expect that governing boards would interact with representation and weaken the relationship between shifts in minority representation and policy outcomes.

H2: States with consolidated governing boards will have a weaker relationship between legislative representation and minority enrollments.

\section{Other Factors that Affect Policy}

In addition to representation and bureaucratic structure, we know that other political and bureaucratic factors can greatly influence policy outcomes. In the case of higher education, we must also control for changes in the constitutionality of the use of race in admissions, the vast difference among institutions within the higher education system, and the effects of various state-level political and demographic fluctuations.

\section{Restrictions on Using Race}

Most of the attention over minority enrollments has focused on discussing affirmative action policies, and the courts have fluctuated on what would be allowed. The constitutionality of affirmative action programs over time has depended on the location of the university, the year, and the nuances of the policy. The arguments over the appropriateness of including race in admissions have taken place both in the courts and in state legislatures, but the outcomes of the battles have been virtually identical constraints on institutions. Although the judicial and legislative constraints will be reviewed separately, in the empirical analysis, they will be combined into one variable, representing when universities cannot consider race in admissions.

\section{Judicial Interventions}

Several judicial rulings-Bakke (Regents 1978), Hopwood, and the Michigan cases-each altered a university's ability to include race as a factor in determining admissions and financial aid. Hopwood, the 1996 ruling of the $5^{\text {th }}$ Circuit Court of Appeals, restricted all use of race in admissions' decisions for public universities in Louisiana, Mississippi, and Texas, eliminating those universities' ability to attract minority students through race-targeted admissions policies. Hopwood's limited jurisdiction meant that American universities were without a common standard until 2003, when the Supreme Court ruled again on the use of race in admissions policies. The Michigan cases (Grutter and Gratz) lifted the Hopwood ban on race but still placed some restrictions on how a university incorporates race into admissions.

\section{Legislative Policies}

Some states also passed laws that precluded the use of race in admissions, often substituting other policies that attempted to increase diversity, without giving preference to certain groups. These state laws were passed in response to Hopwood, in states that were not bound under the $5^{\text {th }}$ circuit court. California's Proposition 209 and Florida's "One Florida" policy restricted institutions in those states from incorporating race into admissions. This limited many institutions in their pursuit of diversity, and each state received considerable criticism. This study will test the effect of these judicial interventions and state restrictions on race.

H3: Restricting the use of race in admissions is negatively associated with levels of minority student enrollment.

\section{University Characteristics}

Some of the more interesting questions about how state-level factors affect policy outcomes are not focused on their direct effects, but on how the relationship between state-level factors and policy 
outcomes is moderated by the bureaucracy (hypothesis two), or in this case, university-specific characteristics. One substantial difference between universities is their level of selectivity. Selectivity, a measure of competitiveness or prestige, affects almost every facet of a university - type of students, mission, curriculum, faculty, budgets, etc. Not considering how differences in institutional selectivity play a role in policy would be to ignore a critical component of the higher education policy environment. This is why the existing literature on affirmative action in university admissions is so limited in generalizability. Only including Ivy League and flagship universities ignores the importance of varying levels of selectivity.

Previous research has shown that the institution's level of selectivity has a significant moderating effect on the relationship between race restrictions and minority enrollments for universities bound under Hopwood and California's Proposition 209 (Hicklin 2007). Because the inclusion of race into admissions is intended to give minority students a more competitive edge in gaining admissions, universities with open enrollment policies would not see the inclusion of race as a means to increase minority enrollment. If everyone who meets the minimum requirement is already accepted, the value of providing an extra edge is limited. Alternatively, if a university is very selective, any advantage is significant. Because most previous research does not include universities of varying selectivity, we know little about how these differences affect outcomes.

H4: The effect of race restrictions on minority student enrollment depends on the institution's level of selectivity.

Other institutional-specific characteristics will be included in this study as well. Because public universities compete in a market (though not a free market) for minority students, some measure of cost should be included. Only in the last few years, however, have many states deregulated tuition and seen significant differences among public universities. Compared to the differences between public and private schools, which can exceed $\$ 30,000$ a year, differences among public universities are almost negligible. This may soon change, as state budgets have not kept up with the increasing costs of education, and universities have been forced to generate a greater percentage of their budget through tuition and fees. To reflect these cost differences, we include both a measure of tuition and fees and a measure of the average amount of money a student receives in financial aid.
Additionally, for us to substantiate that these fluctuations in policy outcomes can be attributed to variations in descriptive representation and structure, we have to control for the competing hypothesis: that this is all an issue of ideology. Support for minority groups on various policy issues has consistently been tied to a more liberal citizenry, and it is important that our models consider these differences. More importantly, the inclusion of citizen ideology allows us to further test our hypothesis about structure. In many ways, our hypothesis about bureaucratic structure argues that more autonomous bureaucratic agencies will weaken the core democratic relationship between legislative preferences and policy. If the effect of varying structures is truly found in its ability to dampen the translation of public will to policy, we might also expect variations in structure to weaken the influence of citizen ideology on policy outcomes. To further test our hypothesis concerning varying structures, we include an interaction of structure and citizen ideology. In an effort to control for other differences in the state's political environment, we also include party of the governor and partisanship of the legislature.

Finally, in the case of minority student enrollments, we have to incorporate key differences among states and institutions that are particularly relevant in studying issues of race. First, we control for fluctuations in the growth of the minority community in the state, by including a variable measuring the growth in African American and Hispanic population. ${ }^{3}$ Secondly, we know that some public universities have identified serving African American students as their primary mission. Many of these universities date back into the mid-1800s and now carry the designation "historically black colleges and universities" (HBCUs). HBCUs are often given special consideration by the state and federal governments through additional appropriations. These universities also have a strong reputation in minority communities that cannot quite be captured in any way other than with their HBCU status.

\section{Data and Methods}

The data for this project have been compiled from numerous sources. Student enrollment data, tuition

\footnotetext{
${ }^{3}$ We have received some questions as to whether structure might also mediate the relationship between population shifts and outcomes. We did not find empirical support for this relationship, and we have included a separate analysis with that interaction in the the online appendix at http://journalofpolitics.org/.
} 
data, and HBCU status is drawn from the Department of Education's Integrated Postsecondary Education Data System (IPEDS) from 1990 to 2001 (IPEDS 2004). University selectivity is based on the competitiveness measure in Barron's Profile of American Colleges (Barron's 2000). State minority legislative representation for African Americans and Latinos is drawn from the Joint Center for Political and Economic Studies (2004) and the National Association of Latino Elected and Appointed Officials (NALEO 2004), respectively. Restrictions on including race for this study's time period were collected from various public media. Party of the governor and partisanship of the legislature are drawn from Klarner (2007), ideology from Berry et al. (1998), and the minority population growth variable is computed using Census projections.

\section{Units of Analysis}

The units of analysis are all American public, four-year universities from 1990 to 2001. Excluded institutions include private universities, community colleges, technical/vocational schools, professional schools, exclusively upper-level schools, and remote campuses. Because of the hierarchical linear modeling software used in this analysis, those universities missing data for any variable in the analysis were dropped from the dataset for that year. The original dataset included 594 universities for the 11 years (with some exceptions), resulting in 5,772 data points. The dataset used in estimation (after dropping those with missing data) included 4,518 cases.

\section{Dependent Variables}

Minority enrollment is operationalized as the percentage of first-time, freshman undergraduate students who are African American and Hispanic, analyzed separately. The first time freshman variable is used because it will be more sensitive to changes in policy and other factors than will total minority enrollment. The decision to use only African American and Hispanic students as the measures of minority enrollments is a pragmatic one. Nationally, Native American students are concentrated in only a few areas, especially in the case of public university enrollment, which causes major problems in estimation and interpretation. Asian Americans, although often considered a minority group, generally have not been identified in the higher education policy arena as "historically disadvantaged." Finally, the use of the term "minority" can be misleading in universities where "minority" students make up the majority of the population, so it is important to note that the term minority is a term used to describe historically underrepresented groups, without any reference to their actual numerical status.

Separate models for African American and Hispanic students explore the differences between these student groups. Practically speaking, universities are often more focused on raising minority enrollments in general, but administrators often have separate strategies for attracting African Americans and Hispanics.

\section{Independent Variables}

This study considers state-level and university-level determinants of minority enrollment. Minority legislative representation is the percentage of the state legislature (both chambers) that is of the same race as the dependent variable (i.e., African American representation used to predict African American student enrollment). ${ }^{4}$ State bureaucratic structure is a dummy variable representing the degree of centralization and autonomy held by the state's chief higher education agency. A "1" represents a more autonomous, centralized governing board, and a " 0 " represents a decentralized coordinating or planning board.

A dummy variable is used to represent the years when state universities are restricted from using race in admissions policies, whether from the courts or the state government $(1=$ restricted, $0=$ unrestricted). Selectivity is an ordinal measure, based on the Barron's Profile of American Colleges (2001) measure of competitiveness. The measure is a 6-point scale, with categories including noncompetitive, less competitive, competitive, more competitive, highly competitive, and most competitive, in that order. Other variables include Berry et al.'s (1998) measure of citizen ideology score, the party of the governor and partisanship of the legislature, and the change in minority population.

Two other control variables are included in these analyses. Although public universities are bureaucratic institutions, they also compete in the market. Because of this, public universities spend substantial amounts of time and money to improve their reputation. In the case of minority enrollments, many universities have reputations for being receptive to minority students. In an effort to account for some of the reputational effect, we added two control

${ }^{4}$ Latino legislative representation was not available for 1996 so these numbers were estimated from 1995. With most state legislatures holding biannual elections, this should not affect the results. 


\section{Table 1 Determinants of Minority Student Enrollment}

\begin{tabular}{|c|c|c|}
\hline Dependent Variable: Percentage of Fir & $\begin{array}{l}\text { Who Are: } \\
\text { African Americans }\end{array}$ & Hispanics \\
\hline Minority Legislative Representation & $0.084^{\star *}(0.015)$ & $0.096^{\star *}(0.011)$ \\
\hline Bureaucratic Structure & $-0.038(0.144)$ & $-0.115^{\star \star}(0.194)$ \\
\hline Representation ${ }^{\star}$ Structure & $-0.059^{\star \star}(0.023)$ & $-0.055^{\star}(0.030)$ \\
\hline Restrictions on Race & $0.858^{\star \star}(0.269)$ & $1.376^{\star \star}(0.351)$ \\
\hline Selectivity & $-0.041(0.042)$ & $0.050(0.032)$ \\
\hline Race Restrictions ${ }^{\star}$ Selectivity & $-0.224^{\star \star}(0.074)$ & $-0.690^{\star \star}(0.177)$ \\
\hline State Citizen Ideology & $0.187^{\star \star}(0.062)$ & $0.175^{\star \star}(0.035)$ \\
\hline Citizen Ideology ${ }^{\star}$ Structure & $-0.489^{\star *}(0.080)$ & $-0.146^{\star \star}(0.050)$ \\
\hline Growth in State's Minority Population & $0.422^{\star \star}(0.152)$ & $-0.070(0.119)$ \\
\hline Partisanship of the State Legislature & $0.027^{\star *}(0.005)$ & $-0.004^{*}(0.002)$ \\
\hline Party of the Governor & $0.315^{\star \star}(0.087)$ & $0.139^{\star *}(0.049)$ \\
\hline Tuition & $-0.022(0.049)$ & $-0.165^{\star \star}(0.048)$ \\
\hline Financial Aid & $-0.033^{\star *}(0.012)$ & $-0.029^{\star *}(0.005)$ \\
\hline $\mathrm{HBCU}$ & $2.754^{*}(1.560)$ & \\
\hline Previous Minority Enrollment & $1.067^{* *}(0.018)$ & $1.266^{* *}(0.028)$ \\
\hline Intercept & $-0.756^{\star *}(0.361)$ & $0.835(0.256)$ \\
\hline $\mathrm{N}$ & 4517 & 4518 \\
\hline
\end{tabular}

${ }^{\dagger} \mathrm{p}=.101$ two tailed test, ${ }^{\star} \mathrm{p}<.10$ two tailed test, ${ }^{* *} \mathrm{p}<.05$ two tailed test

variables. First, we include a dummy variable for those universities designated as a "historically black college or university" (HBCU). Second, we include a variable that measures last year's minority enrollments. Although universities receive new students each year, the previous enrollment numbers tap into the universities' past success in attracting students.

\section{Methodology}

Because these data are drawn from two levels of aggregation (state and university), we used a multilevel approach (hierarchical linear modeling) to estimate the models. The structure of the data, with universities clustered by states, makes OLS an inefficient estimator, violates the assumption that individual errors are independent, and results in artificially low standard errors. The key hypotheses in this study also rely on the hierarchical relationships between states and universities, calling for a multilevel modeling approach (see Gellman and Hill 2007). We estimated the random-intercept portion of the model using all of the state-level determinants. Additionally, to test for the interactive effects of (a) restrictions on using race (a state-level factor) and institutional selectivity (a university-level factor), (b) representation and bureaucratic structure, and (c) ideology and bureaucratic structure, we estimated a random slope model.

\section{Findings}

In evaluating our key hypotheses concerning representation and bureaucratic structure, we find remarkable similarity between the two models but a few key differences (see Table 1). In both models, higher levels of minority representation in the state legislative have a positive and significant effect on the enrollment of minority students. However, the main effect for structure shows that consolidated governing boards negatively correlate with Hispanic student enrollments, but do not seem to have an independent effect on the enrollment of African American students.

The test of hypothesis two can be seen in the interactive term. In both models, the interaction of structure and representation yields a significant, negative coefficient, leading us to conclude that structure is indeed an important mediating factor in the relationship between descriptive representation and substantive policy outcomes. The size of the coefficients for the main effect for representation and the representation-structure interaction show that under consolidated governing boards, the effect of representation is less than half of what it would be under coordinating boards. This shows that structure can be important, and it leads us to believe that varying institutional structures may even account for some of the mixed findings in the descriptive/substantive literature. Had we only examined states with 
consolidated governing boards, we would likely have found modest or even no effect of representation, whereas in coordinating boards, we see a strong, significant effect of representation on policy outcomes.

Our findings concerning structure were also bolstered by the coefficients concerning citizen ideology. Citizen ideology has a direct impact on minority enrollment levels, but in states with governing boards, this impact is reduced to almost 0 for Hispanics and even reversed for African Americans. Again, this outcome adds support to the hypothesis that more autonomous bureaucratic agencies can dampen the translation of political will into policy outcomes.

Our test for the effect of the Hopwood decision confirmed preliminary results from previous studies. The main effect of Hopwood is actually positive and significant, and it is not until we consider the interaction between the Hopwood restriction and the institution's level of selectivity that we can see the effect of abolishing affirmative action. The combination of the positive main effect and negative interaction means that the less selective institutions actually gained minority students when the most selective institutions lost students. Hopwood did not result in a net loss of minority students in those states, but instead produced a "cascading" effect, where minority students began to filter into lessselective institutions.

Unlike our variables of interest, which performed relatively consistently across minority groups and in the predicted direction, our control variables produced mixed results, with the exception of the party of governor, which was positive and significant for both groups. The partisanship of the legislature was significant for both minority groups but in different directions. The coefficients for our financial variables were also mixed, as tuition mattered for Hispanics but not African Americans and financial aid was negatively related to both minority groups. As noted above, this may simply indicate that financial aid has not kept pace with tuition costs. Surprisingly, the growth in the minority population mattered for African Americans but not for Hispanics, but this likely reflects the very young age distribution of the Hispanic population.

\section{Substantive Implications}

Although our primary interest in looking at structure started from a theoretical curiosity in the diversity of findings concerning descriptive representation, we would be remiss to overlook the substantive impor-
FIgURE 1 Effects of Race and Structure over Time

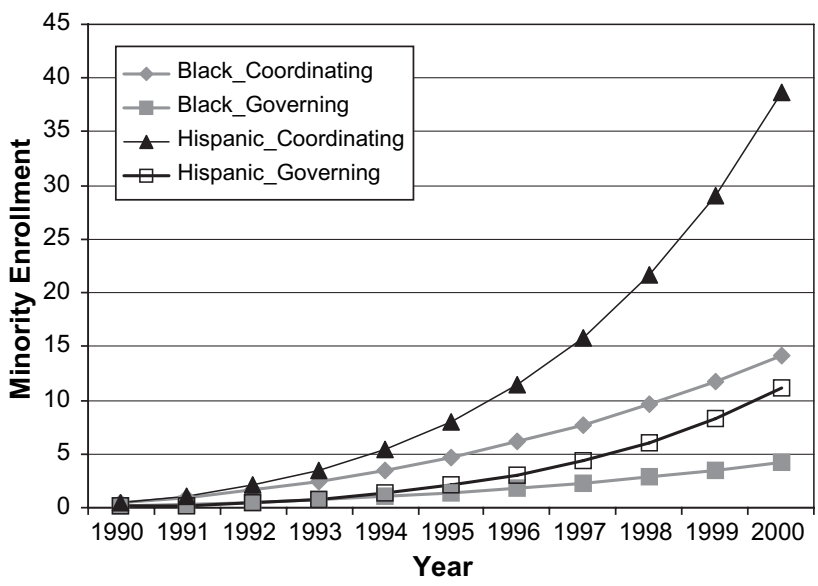

tance of these findings. In examining the effect of minority legislative representation and bureaucratic structure, the findings indicate that the structure of the bureaucracy affects the ability of minority representatives to influence enrollment levels for minority students. In fact, it is in the interactive term where we see the importance of the structure variable. Not only do we see that the interactive term is significant, but it adds to the negative effect of governing boards on student enrollments. These coefficients seem somewhat small, but the coefficient for the variable for the previous year's minority enrollment shows that these institutions are autoregressive, where changes in one year affect future years. This means that we have to consider not only the effect of a variable in one year, but its cumulative effect over a number of years.

This can best be illustrated graphically. Figure 1 depicts a state over 10 years. ${ }^{5}$ At the beginning of the time period, African Americans and Hispanics each represent $5 \%$ of the state legislature, and every other year pick up another $3 \%$, so that 10 years later, each minority group accounts for $20 \%$ of the legislature. Figure 1 uses the coefficients for representation, structure, their interaction, and the lagged dependent variable to show how these fluctuations in representation and structure can affect enrollments.

The graph includes four lines: black representation with a coordinating board, black representation with a governing board, Hispanic representation with a coordinating board, and Hispanic representation with a governing board. Each start out near zero, but over time these lines diverge considerably, with the

\footnotetext{
${ }^{5}$ These projections are roughly based on a particular state in our dataset that experienced significant growth during the time period in question.
} 
two lines for coordinating boards showing remarkable growth compared to governing boards. In the African American model, the difference between a coordinating board and a governing board is $10 \%$, and for Hispanics, this difference is $27 \%$. Even though these differences take a substantial time to emerge, few policy makers and administrators would consider these changes to be negligible, as there are very few other factors that have been identified as having that much influence on enrollments.

\section{Conclusions}

This study uses higher education policy to probe the relationship between minority representation and public policy outcomes and has implications for several theoretically important questions. First, institutional differences, especially among bureaucratic institutions, can affect the relationship between legislative representatives and their constituents. As such this study provides a linkage between the literatures on bureaucracy and policy implementation and the literature on minority representation. The findings suggest that a more complete understanding of representation requires theoretical work and empirical studies that incorporate implementation structures as well as political forces.

Second, the study illustrates the value of using policy indicators that are directly tied to minority interests. Unlike heath care or welfare expenditures, higher education enrollments are clearly a minority goal. A rational representative is likely to focus more effort on such direct policies, and the representation linkages should be stronger there. That these findings hold even with controls for partisanship reinforce their direct linkage to minority interests.

Third, the principal-agent relationships between politicians and bureaucrats are incredibly complex in this area. Not only does structure mediate the impact, but there are numerous agents including board members, university presidents, and university faculty who play a role in this policy area. Governance of higher education is a highly complex process and that complexity makes it fertile ground for additional studies of the interface between bureaucrats and politicians.

Fourth, despite the broad brush similarities for African Americans and Hispanics in this study, there were differences between the two groups. We should expect such differences given the different political histories, different policy agendas, and different levels of political mobilization. Adequate theories of minority politics need to bring theoretical understanding to these differences so that systematic analysis can determine the general findings applicable to all groups and the specific findings that are unique to an individual group.

\section{Acknowledgement}

Special thanks to Dave Peterson, Kim Hill, Rene Rocha, and the suggestions of our very conscientious reviewers.

Manuscript submitted 26 September 2005

Manuscript accepted for publication 15 September 2007

\section{References}

Barron's Profile of American Schools. 2000. New York: Barrons Educational Series.

Berry, William D., Evan Ringquist, Richard Fording, and Russell Hanson. 1998. "Measuring Citizen and Government Ideology in the American States, 1960-93." American Journal of Political Science 42 (1): 327-48.

"Beyond Percentage Plans: The Challenge of Equal Opportunity in Higher Education." 2002. U.S. Commission on Civil Right. http://www.usccr.gov/pubs/percent2/percent2.pdf.

Bowen, William, Derek Bok, and Glenn C. Loury 2000. The Shape of the River. Princeton: Princeton University Press.

Bratton, Kathleen A., and Kerry L. Haynie 1999. Agenda Setting and Legislative Success in State Legislatures: The Effects of Race and Gender. Journal of Politics 61 (3): 658-79.

Cameron, Charles, David Epstein, and Sharyn O’Halloran. 1996. "Do Majority-Minority Districts Maximize Substantive Black Representation in Congress?" American Political Science Review 90 (4): 794-812.

Chapa, Jorge, and Vincent A. Lazaro 1998. "Hopwood in Texas: The Untimely End of Affirmative Action." Chilling Admissions: The Affirmative Action Crisis and the Search for Alternatives. Cambridge: President and Fellows of Harvard College.

Duderstadt, James. 2000. A University for the $21^{\text {st }}$ Century. Ann Arbor: University of Michigan Press.

Epstein, David, and Sharyn O'Halloran. 1999. Delegating Powers: A Transaction Cost Politics Approach to Policy Making under Separate Powers. Cambridge: Cambridge University Press.

Fraga, Luis Ricardo, Kenneth J. Meier, and Robert England. 1986. "Hispanic Americans and Education Policy: Limits to Equal Access." Journal of Politics 48 (4): 850-76.

Gellman, Andrew, and Jennifer Hill. 2007. Data Analysis Using Regression and Multilevel Modeling. New York: Cambridge University Press.

Gratz v. Bollinger, No. 02-516. 2003.

Grose, Christian. 2006. "Disentangling Constituency and Legislator Effects in Legislative Representation." Social Science Quarterly 86 (2): 427-43.

Grutter v. Bollinger, No. 02-241. 2003.

Hero, Rodney E., and Caroline Tolbert. 1998. "Latinos and Substantive Representation in the U.S. House of Representatives." American Journal of Political Science 39 (3): 640-52. 
Hicklin, Alisa. 2007. "The Effect of Race-Based Admissions in Public Universities: Debunking the Myths about Hopwood and Proposition 209." Public Administration Review 67 (2): 331-40.

Hopwood v. Texas. 78 F.3d. 932. 1996.

Horn, Catherine L., and Stella M. Flores. 2003. "Percent Plans in College Admissions: A Comparative Analysis of Three State's Experiences." The Civil Rights Project. http://www. civilrightsproject.harvard.edu.

Hurtado, Sylvia, and Heather Wathington Cade. 2001. "Time for Retreat or Renewal? Perspectives on the Effects of Hopwood on Campus." In The States and Public Higher Education Policy: Affordability, Access, and Accountability, ed. Donald Heller. Baltimore: The John Hopkins University Press, 100-20.

Huber, John D., and Charles R. Shipan 2002. Deliberate Discretion? The Institutional Foundations of Bureaucratic Autonomy. Cambridge: Cambridge University Press.

IPEDS. 2004. Integrated Postsecondary Education Data System. http://nced.ed.gov/ipeds/.

Joint Center for Political and Economic Studies. 2004. Black Elected Officials. http://www.jointcenter.org.

Karnig, Albert K. and Susan Welch. 1999. Black Representation and Urban Policy. Chicago: University of Chicago Press.

Klarner, Carl. 2007. "Measurement of Partisan Balance of State Government.” SPPQ Data Resource. http://www.ipsr.ku.edu/ SPPQ/journal_datasets.shtml.

Knight, Jack. 1992. Institutions of Social Conflict. Cambridge: Cambridge University Press.

Knott, Jack H. and A. Abigail Payne. 2003. "The Impact of State Governance Structures on Management and Performance of Public Organizations: A Study of Higher Education Institutions." Journal of Policy Analysis and Management 23 (1):13-30.

Lowry, Robert. 2001. "Governmental Structure, Trustee Selection, and Public University Prices and Spending: Multiple Means to Similar Ends." American Journal of Political Science 45 (4): 845-61.

Lublin, David. 1999. The Paradox of Representation. Princeton: Princeton University Press.

Mansbridge, Jane. 1999. "Should Blacks Represent Blacks and Women Represent Women? A Contingent Yes." Journal of Politics. 61 (3): 628-57.

McLendon, Michael K. 2003. "State Governance Reform of Higher Education." Higher Education: Handbook of Theory and Research. XVIII. New York: Agathon Press.

McLendon, Michael K., Donald E. Heller, and S. Young 2005. "State Postsecondary Policy Innovation: Politics, Competi- tion, and Interstate Migration of Policy Ideas." The Journal of Higher Education 76 (4): 363-400.

Meier, Kenneth J., Eric Gonzalez Juenke, Robert D. Wrinkle, and J. L. Polinard 2005. "Structural Choices and Representational Biases: The Post-Election Color of Representation." American Journal of Political Science 49 (October): 758-69.

Meier, Kenneth J., and Joseph Stewart. 1991. The Politics of Hispanic Education: Un paso pa'lante y dos pa'tras. Albany: State University of New York Press.

Meier, Kenneth J., Joseph Stewart, and Robert E. England 1989. Race, Class, and Education: The Politics of Second Generation Discrimination. Madison: University of Wisconsin Press.

NALEO. 2004. National Association of Latino Elected and Appointed Officials. http://www.naleo.org.

Payne, A. Abigail. 2003. "The Role of Politically Motivated Subsidies on University Research Activities." Educational Policy 17 (January): 12-37.

Pitkin, Hanna. 1967. The Concept of Representation. Berkeley: University of California Press.

Post, Robert. 1998. "Introduction: After Bakke." Race and Representation: Affirmative Action.” New York: Zone Books.

Preuhs, Robert R. 2006. "The Conditional Effects of Minority Representation." Journal of Politics 68 (3): 585-99.

Regents of the University of California v. Bakke, 438 US 265. 1978.

Rourke, Francis E. 1969. Bureaucracy, Politics, and Public Policy. Boston: Little Brown.

Simmons, Ron. 1982. Conflict and Change in Higher Education after Bakke. Cambridge: Schenkman.

"Statistical Abstract of the United States." 2001. U.S. Census Bureau. http://www.census.gov/prod/www/statistical-abstractus.html.

Welch, Susan, and John Gruhl. 1998. Affirmative Action and Minority Enrollments in Medical and Law Schools. Ann Arbor: University of Michigan.

Alisa Hicklin is assistant professor of political science, University of Oklahoma, Norman, OK 73019. Kenneth J. Meier is distinguished professor of political science, Texas A \& M University and Cardiff University, College Station, TX 77843. 